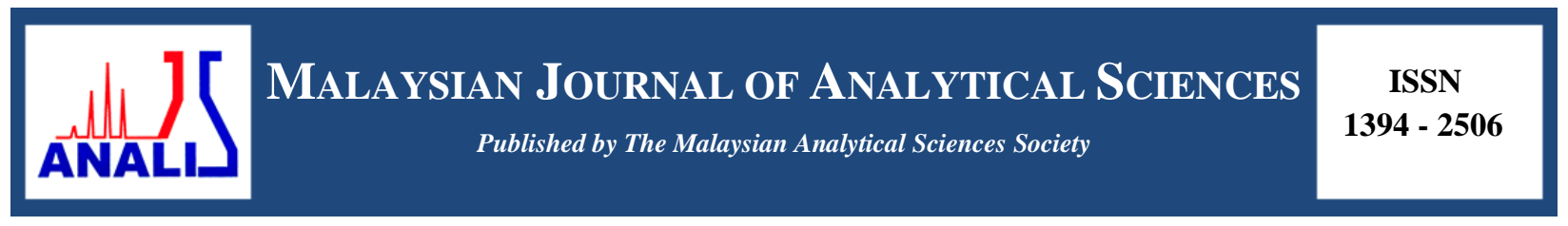

\title{
METHOD DEVELOPMENT AND VALIDATION FOR QUANTIFICATION OF CORTISOL AND CORTISONE USING ULTRA-HIGH PERFORMANCE LIQUID CHROMATOGRAPHY-TANDEM MASS SPECTROMETRY
}

\section{(Pembangunan dan Pengesahan Kaedah untuk Kuantifikasi Kortisol dan Kortison Menggunakan Kromatografi Cecair Berprestasi Ultra Tinggi-Spektrometri Jisim Gabungan)}

\author{
Hazirah Abd Azhar ${ }^{1,2}$, Mohd Salleh Rofiee ${ }^{1}$, Mohammad Zulfadhly Jan Jam ${ }^{1}$, Muhammad Hisyam Jamari ${ }^{1}$, \\ Roziah Mohd Janor ${ }^{1,3}$, Richard Johari James ${ }^{1,2} *$, Teh Lay Kek ${ }^{1,2}$, Mohd Zaki Salleh ${ }^{1,2}$ \\ ${ }^{1}$ Integrative Pharmacogenomics Institute (iPROMISE) \\ ${ }^{2}$ Faculty of Pharmacy \\ Universiti Teknologi MARA Puncak Alam Campus, 42300 Bandar Puncak Alam, Selangor, Malaysia \\ ${ }^{3}$ Faculty of Computer \& Mathematical Sciences, \\ Universiti Teknologi MARA Shah Alam Campus, 40450 Shah Alam, Selangor, Malaysia \\ *Corresponding author: richard@uitm.edu.my
}

Received: 30 May 2018; Accepted: 14 April 2019

\begin{abstract}
Cortisol and its metabolite cortisone have been used as a biological marker of stress in human psychobiological studies. Cortisol and cortisone quantitation may help to examine physiological responses towards stress. A highly sensitive and selective ultrahigh performance liquid chromatography tandem mass spectrometry (UHPLC-MS/MS) method was developed for simultaneous quantitation of cortisol and cortisone in human serum. These two compounds were chromatographically separated using Agilent ZORBAX Eclipse Plus $\mathrm{C}_{18}$ Rapid Resolution HD column $(2.1 \mathrm{~mm} \times 50 \mathrm{~mm}, 1.8 \mu \mathrm{m})$ and were eluted with (A) $0.1 \%$ formic acid in water and (B) methanol mobile phase. The sample injection volume was $2 \mu \mathrm{L}$ and the flow rate was set at $0.3 \mathrm{~mL} / \mathrm{min}$. The analytes were determined in positive ionization mode and quantitated by multiple-reaction monitoring (MRM) mode. The method was linear from 7.8 to $500 \mathrm{ng} / \mathrm{mL}$ for cortisol $\left(\mathrm{r}^{2}=0.986\right)$ and cortisone $\left(\mathrm{r}^{2}=0.990\right)$. The precision, accuracy, and recovery of the method for cortisol ranged from 1.98-10.46\%, 90.68-91.94\%, 90.38-93.88\%, and cortisone ranged from 1.01 $11.36 \%, 93.12-94.79 \%$ and $90.48-95.90 \%$, respectively. The developed method has met the quality standards of European Medicines Agency (EMA).
\end{abstract}

Keywords: cortisol, cortisone, serum, ultra-high performance liquid chromatography-tandem mass spectrometry

\begin{abstract}
Abstrak
Kortisol dan metabolitnya kortison telah digunakan sebagai penanda tekanan biologi untuk mengkaji psikobiologi manusia. Pengkuantitian kortisol dan kortison boleh membantu untuk menilai tindak balas fisologi terhadap tekanan. Kaedah kromatografi cecair berprestasi ultra tinggi -spektrometri jisim gabungan yang sangat sensitif dan selektif telah dibangunkan untuk pengkuantitian kortisol dan kortison secara serentak di dalam serum manusia. Kedua-dua sebatian ini telah dipisahkan secara kromatografi menggunakan turus Agilent ZORBAX Eclipse Plus $\mathrm{C}_{18}$ Resolusi Pantas HD $(2.1 \mathrm{~mm} \times 50 \mathrm{~mm}, 1.8 \mu \mathrm{m})$ dengan campuran fasa bergerak (A) $0.1 \%$ asid formik dalam air dan (B) metanol. Jumlah suntikan sampel adalah $2 \mu \mathrm{L}$ dan kadar aliran ditetapkan pada $0.3 \mathrm{~mL} / \mathrm{min}$. Analisis ini telah ditentukan dalam mod pengionan positif dan dikira oleh mod pemantauan pelbagai tindak balas. Kaedah ini adalah linear dari 7.8 hingga $500 \mathrm{ng} / \mathrm{mL}$ untuk kortisol $\left(\mathrm{r}^{2}=0.986\right)$ dan kortison $\left(\mathrm{r}^{2}=0.990\right)$. Ketepatan, kejituan dan kadar pemulihan untuk kortisol adalah antara 1.98-10.46\%, 90.68-91.94\%, 90.38-93.88\%, dan kortison terdiri daripada $1.01-11.36 \%, 93.12-94.79 \%$ dan $90.48-95.90 \%$. Kaedah yang dibangunkan telah memenuhi piawaian kualiti agensi perubatan eropah (EMA).
\end{abstract}




\section{Hazirah et al: METHOD DEVELOPMENT AND VALIDATION FOR QUANTIFICATION OF CORTISOL AND CORTISONE USING ULTRA-HIGH PERFORMANCE LIQUID CHROMATOGRAPHY- TANDEM MASS SPECTROMETRY}

Kata kunci: kortisol, kortison, serum, kromatografi cecair berprestasi ultra tinggi - spektrometri jisim gabungan

\section{Introduction}

Cortisol is the main glucocorticoid hormone produced by the adrenal cortex that regulates the metabolism of carbohydrates, proteins and lipids. Its synthesis is stimulated through a hypothalamic-adrenal-pituitary feedback system. Cortisol hormone in human body undergoes diurnal variation where the level is high early in the morning and reaches its lowest level at midnight [1,2]. Cortisol is involved in the feedback mechanism of the immune system that suppresses immune activity, thus it is used to treat overactive immune diseases such as allergies, asthma, inflammatory disorder and autoimmune disease [3]. Cortisone is interconverted to the inactive metabolite of cortisol by enzymes $11 \beta$-hydroxysteroid dehydrogenase (11ßHSD) [4-6].

Cortisol has been associated with physiological response towards depression, anxiety and stress [7-9]. Stress has been reported to increase the activity of the hypothalamus-pituitary-adrenal (HPA) axis with a subsequent rise in cortisol level $[10,11]$. Thus, serum cortisol concentration may serve as a diagnostic tool for depressive disorder and stress. Low levels of cortisol are seen in patients with rare adrenal enzyme defects and after long-lasting stress. Uncontrolled stress has been associated with increased risk of several health complications such as heart disease, diabetes, immunosuppression and cognitive impairment [12]. Research by the Institute for Public Health reported that estimated $29.9 \%$ of adults in Malaysia are experiencing mental health problems such as depression and anxiety. The increasing trend of mental health problems from the prevalence of 10.7\% estimated in 1996 demands close attention towards this issue [13]. Besides, a study by Armitage et al., stated that the prevalence of suicide in Malaysia was six to eight per 100000 population per year [14]. This figure indicates a high prevalence of psychiatric morbidity among Malaysian. Thus, proper intervention to monitor stress level in the Malaysian context is required.

Clinically, cortisol is measured directly from biological samples using immunoassays. However, this method has been known to have disadvantages such as sample matrix effect and cross-reactivity with endogenous steroid, lipids or metabolites which affect the method specificity [15-17]. Furthermore, low levels of serum cortisol and cortisone and similarity in their chemical structure, make this analysis a challenge [18]. Therefore, a highly specific and sensitive analytical tool is needed to quantitate the concentration of the two closely identical molecules such as cortisol and cortisone in biological samples. In this respect, quantitative analysis of low-concentration analytes is possible by using a highly reproducible, selective, and sensitive liquid chromatography-tandem mass spectrometry (LC/MS-MS) methods [19-21]. The validated method is useful for investigation of hormone status for the diagnosis and treatment of clinical disorders.

The charcoal-stripped serum has been widely used in biological and cellular studies. Charcoal-stripping of serum is intended to remove a variety of endogenous compounds, including hormones [22]. Since cortisol and cortisone are endogenous steroids, charcoal-stripped serum was used as a blank sample. Several factors contribute to the efficiency of removing hormones using activated charcoal which includes the amount of charcoal and temperature [23]. Pre-treated serum with charcoal powder may reduce matrix effect and increase method selectivity due to the removal of endogenous compounds that might interfere with the target compound [24-26].

The aim of this study was to develop and validate a method for simultaneous quantification of serum cortisol and cortisone using UHPLC-MS/MS according to the guideline outlined by European Medicines Agency (EMA) [27]. Evaluation of the performance of the method includes linearity, accuracy, precision, recovery, matrix effect and stability.

\section{Materials and reagents}

\section{Materials and Methods}

Standards of cortisol (98\%) and cortisone (98\%) were purchased from Sigma-Aldrich Co. (St. Louis, MO, USA). Fluconazole (98\%) as an internal standard (IS) was purchased from Sigma-Aldrich Co. (St. Louis, MO, USA). All the liquid chromatography grade of methanol, acetonitrile and formic acid were purchased from Merck (Darmstadt, 
Germany) and water used in the experiment was purified by using an ELGA PURELAB ultra purification system (Wycombe, Buckinghamshire, UK).

\section{LC-MS/MS characteristics}

Chromatographic separation was performed using Agilent ZORBAX Eclipse Plus $\mathrm{C}_{18}$ Rapid Resolution HD column $(2.1 \mathrm{~mm} \times 50 \mathrm{~mm}, 1.8 \mu \mathrm{m})$ and quantitation was performed on Agilent 6460 triple-quadrupole mass spectrometer equipped with auto-injector and quaternary pump. The injection volume was $2 \mu \mathrm{L}$ and the column temperature was kept constant at $30^{\circ} \mathrm{C}$. The mobile phases utilized used were: (A) distilled water with $0.1 \%$ formic acid and (B) methanol at a flow rate of $0.3 \mathrm{~mL} / \mathrm{min}$. The analytes were separated by a gradient of 0 to 6 minutes with increasing percentage of solvent B from 40 to $70 \%$. Then the solvent ratio was maintained with $70 \%$ solvent B for 30 seconds and decrease gradually from 70 to $40 \%$ of solvent B over for 1.30 minutes. The LC condition was re-equilibrated to initial condition for 2.5 minutes. The analytes were determined in positive ionization mode and quantitated by multiple-reaction-monitoring (MRM) mode. Mass spectrometry was operated in Electrospray ionization (ESI) with Agilent jet stream technology with the optimum gas temperature at $280^{\circ} \mathrm{C}$, gas flow at $12 \mathrm{~L} / \mathrm{min}$, nebulizer at $35 \mathrm{psi}$ and capillary at $4000 \mathrm{~V}$, respectively. Agilent Mass Hunter Qualitative Analysis (B.06.00) and Agilent Mass Hunter Quantitative Analysis (B.07.00) were used for the collection acquisition and analysis of the data.

\section{Serum charcoal-stripping}

Cortisol and cortisone are present in human serum at significant levels. A blank matrix which is free of the target analyte is needed for the preparation of calibration standards and quality control samples. Charcoal-stripping of serum was intended to remove a variety of endogenous compounds, including hormones. Serum samples were obtained from 6 healthy volunteers at Integrative Pharmacogenomics Institute (iPROMISE), Universiti Teknologi MARA. The serum was charcoal-stripped using $1 \mathrm{~g}$ of activated charcoal powder added to $10 \mathrm{~mL}$ of pooled serum followed by incubation for 1 hour with agitation at $55{ }^{\circ} \mathrm{C}$. After centrifugation at $14,000 \mathrm{~g}$ for 30 minutes, the supernatant was separated leaving the charcoal at the bottom and filtered using a $0.22 \mu \mathrm{m}$ filter.

\section{Sample extraction}

Sample extraction was done using a simple protein precipitation in-house method. A $100 \mu \mathrm{L}$ of serum sample was transferred into a tube, $20 \mathrm{ng} / \mathrm{mL}$ of fluconazole as an IS was added followed by $400 \mu \mathrm{L}$ of ice-cold acetonitrile. The tube was vortexed to mix for 30 seconds and centrifuged at 4,100 rpm for 15 minutes at room temperature. The supernatant was transferred to a clean glass tube and evaporated to dryness using concentrator (5301, Eppendorf, Hamburg). The dried sample was reconstituted with $50 \mu \mathrm{L}$ of methanol: water (1:1) followed by 30 seconds vortex mixing, which was then transferred to screw-capped injection vial.

\section{Validation}

The proposed method was validated in accordance with the European Medicines Agency (EMA). The linearity, accuracy, precision, recovery, matrix effect and stability of the method were evaluated. The calibration curves were prepared using charcoal-stripped blank serum spiked with both reference materials using 2-fold serial dilution from $500 \mathrm{ng} / \mathrm{mL}$ to $7.8 \mathrm{ng} / \mathrm{mL}$. Each concentration point level was prepared and assayed in triplicates on 3 different days. The linearity was evaluated by analysing the slope, intercept and correlation coefficient, weight $\left(1 / \mathrm{x}^{2}\right)$ linear leastsquares regression. Intra-day and inter-day precision and accuracy were done by analysing three replicates samples spiked with both reference material at low, medium and high concentration level $(20,200$ and $400 \mathrm{ng} / \mathrm{mL})$ on the same day and on 3 different days for inter-day validation. The accuracy was evaluated by comparing the measured concentration with the true value and the precision was expressed as the relative standard deviation percentage $(\mathrm{RSD} \%)$.

The extraction recovery was determined by comparing the peak areas from serum spiked before extraction with those spiked after extraction. The matrix effect was determined using the ratio of peak areas of the blank serum spiked after extraction with those of pure standard solution containing the same amount of the analyte. Then the coefficient variation of the IS-normalised matrix effect was assessed by dividing the matrix effect of the analyte by the matrix effect of the IS. The stability of the analytes in serum was assessed by analysing the spiked serum samples and kept at room temperature for 24 hours, in autosampler at $10{ }^{\circ} \mathrm{C}$ for overnight and three times freeze- 


\section{Hazirah et al: METHOD DEVELOPMENT AND VALIDATION FOR QUANTIFICATION OF CORTISOL AND CORTISONE USING ULTRA-HIGH PERFORMANCE LIQUID CHROMATOGRAPHY- TANDEM MASS SPECTROMETRY}

thaw cycles at $-80^{\circ} \mathrm{C}$ and compare to a freshly prepared QC sample. Three replicates were analysed for each storage condition at low, medium and high concentrations $(20,200$ and $400 \mathrm{ng} / \mathrm{mL})$.

\section{Results and Discussion}

An LC-MS/MS method for simultaneous quantitation of cortisol and cortisone concentration in human serum was developed and validated. Collision-induced dissociation was performed to produce two product ions that act as quantifier and qualifier. Quantifier and qualifier transitions used are described in Table 1.

Table 1. Quantifier and qualifier transition

\begin{tabular}{lcc}
\hline Compound & Quantifier $\mathbf{~} / \mathbf{z}$ & Qualifier $\mathbf{m} / \mathbf{z}$ \\
\hline Cortisol & $363.2>121.1$ & $363.2>91.1$ \\
Cortisone & $361.2>163.1$ & $361.2>121.1$ \\
Fluconazole (IS) & $307.1>238.1$ & $307.1>220.0$ \\
\hline
\end{tabular}

Gradient elution of mobile phase with $0.3 \mathrm{~mL} / \mathrm{min}$ flow rate was suggested as a suitable method for complete and rapid separation of cortisol and cortisone. Figure 1 shows typical chromatograms for cortisol, cortisone and IS in serum. The retention times for cortisol, cortisone and IS were 5.46, 4.87 and 1.47 minute, respectively. The chromatograms show good separation with a sharp peak of target analytes, low background noise, and there are no significant interfering peaks from the sample matrix indicated that the method is highly selective to the target analytes. These results also indicated the rapid analytical time and high specificity should facilitate high throughput measurement of both cortisol and cortisone simultaneously in human serum.

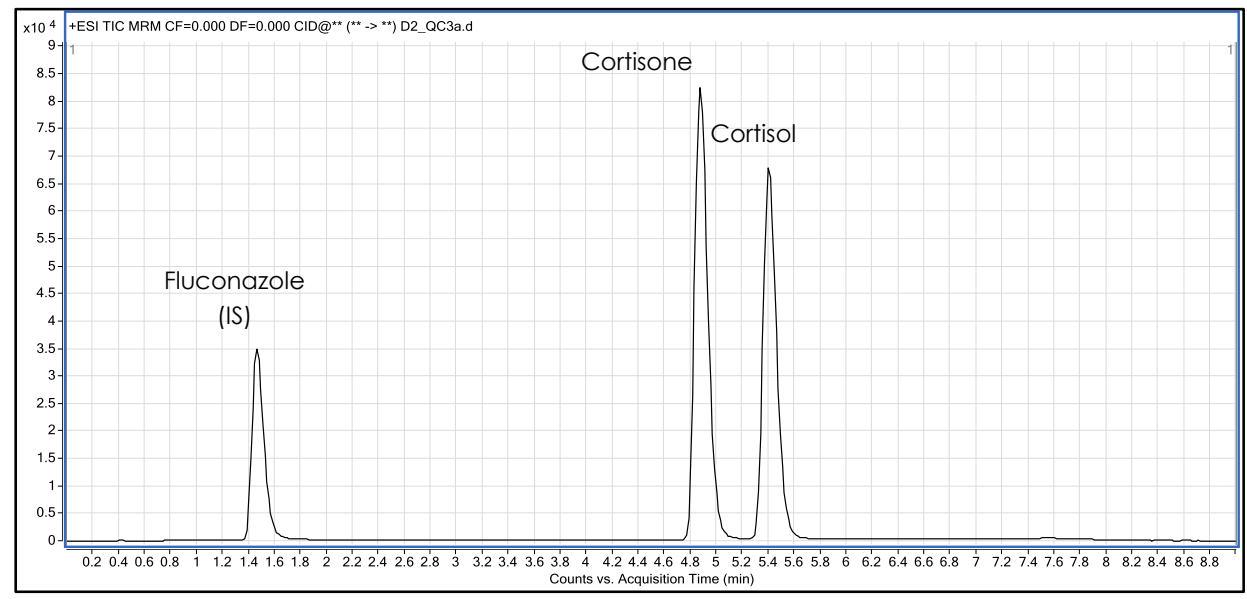

Figure 1. Chromatograms of cortisol, cortisone and fluconazole

The presence of endogenous cortisol and cortisone in the serum makes it difficult for method validation analysis. Several studies have used pooled human serum as a blank matrix $[19,28]$. However, using pooled serum may cause variation in the baseline cortisol and cortisone concentration for different batches of pooled serum. Thus, the method used is neither consistent nor reproducible for long period or across laboratories. Another method adopted to overcome this problem is by using charcoal-stripped serum or plasma as a blank matrix to prepare calibration standard and quality control samples [3, 29, 30]. A study by Cao et al. revealed that charcoal treatment may completely or nearly completely extracted cortisol hormone present in fetal bovine serum and bovine calf serum [22]. In this study, activated charcoal powder was used to remove endogenous cortisol and cortisone from pooled human serum. The results demonstrate that activated charcoal powder efficiently removes endogenous cortisol and cortisol from human serum at the level lower than the detection limit, as shown in Figure 2. Both compounds were 
removed from serum by 1 hours of incubation at $55^{\circ} \mathrm{C}$ with $1 \mathrm{~g} / \mathrm{mL}$ of activated charcoal powder. The high amount of charcoal powder attributed to the greater availability of surface area and increase the adsorption site and the high in temperature also contributed to the removal of the hormones where thermodynamic effect facilitates the sorption process [23]. The resultant cortisol and cortisone free serum is a suitable blank matrix for method validation analysis.
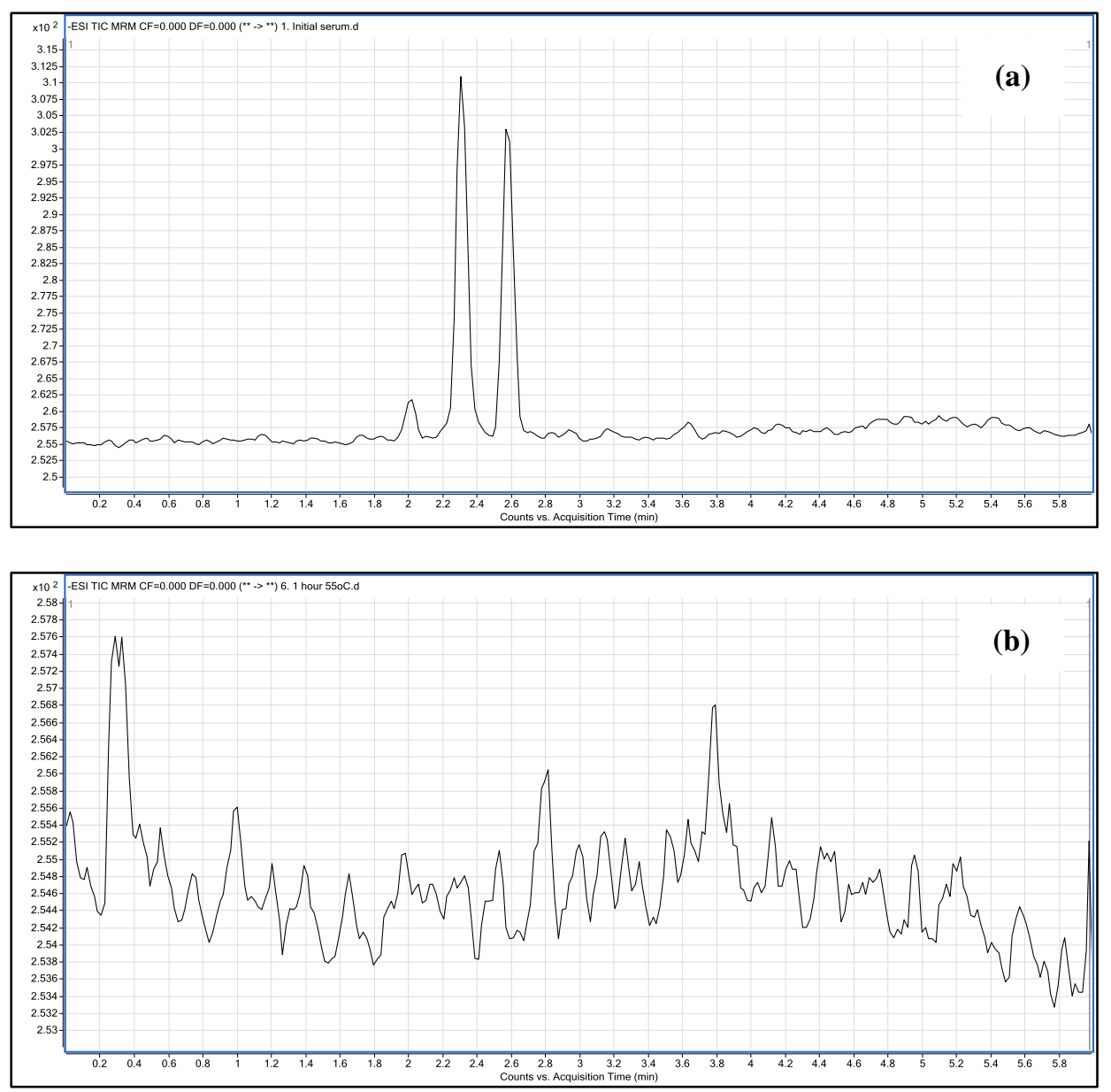

Figure 2. Chromatogram of pooled human serum samples (a) prior to and (b) after the removal of cortisol and cortisone by charcoal-stripping method

The correlation coefficients $\left(\mathrm{r}^{2}\right)$ of the calibration curves are 0.98 for cortisol and 0.99 for cortisone over the range of 7.8-500 ng/mL, indicating good linearity (Table 2). Accuracy and precision data are presented in Table 3. Intraday accuracy ranges from 90.68 to $91.94 \%$ for cortisol and 93.12 to $94.79 \%$ for cortisone, while precision ranges from 1.98 to 10.46 for cortisol and 1.01 to 11.36 for cortisone. Inter-day accuracy ranges from $94.50 \%$ to $104.28 \%$ for cortisol and $100.70 \%$ to $104.28 \%$ for cortisone, while precision ranges from $7.18 \%$ to $11.00 \%$ for cortisol and $11.07 \%$ to $15.78 \%$ for cortisone. All the accuracy results are within the limit of $\pm 15 \%$ and precision results are below 15\% except for inter-day precision for cortisone where the result is slightly high. The results obtained using this method produced equivalent results from a previous study [3]. 
Hazirah et al: METHOD DEVELOPMENT AND VALIDATION FOR QUANTIFICATION OF CORTISOL AND CORTISONE USING ULTRA-HIGH PERFORMANCE LIQUID CHROMATOGRAPHYTANDEM MASS SPECTROMETRY

Table 2. The regression equation, correlation coefficients $\left(r^{2}\right)$, linear range and lower limit of quantitation data

\begin{tabular}{lccc}
\hline Compound & Regression Equation & $\begin{array}{c}\text { Correlation } \\
\text { Coefficients }\left(\mathbf{r}^{\mathbf{2}}\right)\end{array}$ & $\begin{array}{c}\text { Linear Range } \\
(\mathbf{n g} / \mathbf{m L})\end{array}$ \\
\hline Cortisol & $0.112255 \mathrm{X}+0.003791$ & 0.98 & $7.8-500$ \\
Cortisone & $0.166686 \mathrm{X}+0.004023$ & 0.99 & $7.8-500$ \\
\hline
\end{tabular}

Table 3. Precision and accuracy data

\begin{tabular}{|c|c|c|c|c|c|c|c|}
\hline \multirow[b]{2}{*}{ Compound } & \multirow[b]{2}{*}{$\begin{array}{c}\text { Spiked } \\
\text { Concentration } \\
(\mathrm{ng} / \mathrm{mL})\end{array}$} & \multicolumn{3}{|c|}{ Intra-day } & \multicolumn{3}{|c|}{ Inter-day } \\
\hline & & $\begin{array}{c}\text { Mean } \\
\text { Measured } \\
\text { Concentration } \\
(\mathbf{n g} / \mathbf{m L})\end{array}$ & $\begin{array}{c}\text { Precision } \\
\text { (RSD\%) }\end{array}$ & $\begin{array}{c}\text { Accuracy } \\
(\%)\end{array}$ & $\begin{array}{c}\text { Mean } \\
\text { Measured } \\
\text { Concentration } \\
(\mathbf{n g} / \mathbf{m L})\end{array}$ & $\begin{array}{c}\text { Precision } \\
\text { (RSD\%) }\end{array}$ & $\begin{array}{c}\text { Accuracy } \\
(\%)\end{array}$ \\
\hline \multirow{3}{*}{ Cortisol } & 20 & 18.14 & 10.46 & 90.68 & 18.92 & 7.18 & 94.50 \\
\hline & 200 & 183.89 & 2.20 & 91.94 & 208.56 & 10.37 & 104.28 \\
\hline & 400 & 366.47 & 1.98 & 91.62 & 414.42 & 11.00 & 103.61 \\
\hline \multirow{3}{*}{ Cortisone } & 20 & 18.67 & 11.36 & 93.33 & 20.14 & 15.78 & 100.70 \\
\hline & 200 & 186.23 & 1.01 & 93.12 & 207.21 & 11.07 & 103.61 \\
\hline & 400 & 379.17 & 1.02 & 94.79 & 417.13 & 13.27 & 104.28 \\
\hline
\end{tabular}

Extraction recovery and matrix effect data are shown in Table 4. The mean recoveries of serum samples spiked with standards at a low, medium and high concentration $(20,200$ and $400 \mathrm{ng} / \mathrm{mL})$ are $93.88 \%, 90.38 \%$ and $92.09 \%$ for cortisol and $95.90 \%, 90.48 \%$ and $92.54 \%$ for cortisone, respectively. This method managed to achieve high analyte recovery using a simple and cost-effective protein precipitation method as compared to the solid phase extraction (SPE) method [5]. The IS-normalized matrix effect of serum samples at all concentration levels are within the limit which is less than $15 \%$.

Stability data are presented in Table 5 . The stability test was done at three different conditions which were 24 hours room temperature, overnight in autosampler $\left(10^{\circ} \mathrm{C}\right)$ and three times freeze-thaw cycles $\left(-80^{\circ} \mathrm{C}\right)$. The stability value for both compounds in autosampler $\left(10^{\circ} \mathrm{C}\right)$ overnight are within the limit which is $\pm 15 \%$ of the nominal concentration. However, cortisol and cortisone compounds are not stable at medium and high concentration levels at 24-hour room temperature and both compounds are not stable at all concentration levels in three times freeze-thaw cycles $\left(-80^{\circ} \mathrm{C}\right)$. The variation in analyte measurement that exceeded the acceptance limit could be due to the room temperature and evaporation effects [31]. Thus, to maintain the integrity of the results, samples should avoid these conditions that may cause instability of the compounds.

Table 4. Mean extraction recoveries and matrix effects of the cortisol and cortisone

\begin{tabular}{lcccccc}
\hline \multirow{2}{*}{ Compound } & \multicolumn{3}{c}{$\begin{array}{c}\text { Mean Extraction Recovery } \\
(\%)\end{array}$} & \multicolumn{3}{c}{$\begin{array}{c}\text { IS-Normalized Matrix Effect } \\
(\%)\end{array}$} \\
\cline { 2 - 7 } & Low & Medium & High & Low & Medium & High \\
\hline Cortisol & 93.88 & 90.38 & 92.09 & 13.30 & 4.25 & 8.40 \\
Cortisone & 95.90 & 90.48 & 92.54 & 7.94 & 8.34 & 7.26 \\
\hline
\end{tabular}


Table 5. Stability of the two analytes in 3 different conditions

\begin{tabular}{|c|c|c|c|c|c|c|c|}
\hline \multirow{2}{*}{ Compound } & \multirow{2}{*}{$\begin{array}{c}\text { Freshly } \\
\text { Prepared } \\
\text { Sample } \\
(\text { ng/mL) }\end{array}$} & \multicolumn{2}{|c|}{$\begin{array}{c}\text { Overnight in Autosampler } \\
\left(10^{\circ} \mathrm{C}\right)\end{array}$} & \multicolumn{2}{|c|}{$\begin{array}{l}24 \text { Hours at Room } \\
\text { Temperature }\end{array}$} & \multicolumn{2}{|c|}{$\begin{array}{l}\text { Three Times Freeze- } \\
\text { Thaw Cycles }\left(-80^{\circ} \mathrm{C}\right)\end{array}$} \\
\hline & & $\begin{array}{c}\text { Measured } \\
\text { Concentration } \\
(\mathbf{n g} / \mathbf{m L})\end{array}$ & $\begin{array}{l}\text { Stability } \\
\quad(\%)\end{array}$ & $\begin{array}{c}\text { Measured } \\
\text { Concentration } \\
(\mathbf{n g} / \mathbf{m L})\end{array}$ & $\begin{array}{l}\text { Stability } \\
\quad(\%)\end{array}$ & $\begin{array}{c}\text { Measured } \\
\text { Concentration } \\
(\mathrm{ng} / \mathrm{mL})\end{array}$ & $\begin{array}{l}\text { Stability } \\
(\%)\end{array}$ \\
\hline \multirow{3}{*}{ Cortisol } & 18.70 & 21.18 & 113.52 & 20.64 & 110.73 & 15.73 & 84.24 \\
\hline & 223.15 & 224.83 & 100.75 & 281.47 & 126.15 & 168.04 & 75.30 \\
\hline & 417.20 & 431.48 & 103.05 & 503.74 & 121.01 & 342.17 & 82.13 \\
\hline \multirow{3}{*}{ Cortisone } & 19.40 & 21.22 & 109.62 & 19.74 & 101.96 & 16.40 & 84.6 \\
\hline & 222.99 & 221.18 & 99.19 & 269.63 & 120.92 & 174.81 & 78.39 \\
\hline & 418.18 & 424.88 & 101.30 & 493.80 & 118.27 & 352.33 & 84.32 \\
\hline
\end{tabular}

\section{Conclusion}

Charcoal-stripped serum was used for method validation process and a highly selective, sensitive reliable and rapid quantitation method for cortisol and cortisone that fulfilled the criteria of European Medicines Agency (EMA) was developed and validated. The method developed may be useful to assess physiological response towards depression, anxiety and stress in future research work.

\section{Acknowledgment}

The authors fully acknowledged the Ministry of Education, Malaysia through the Fundamental Research Grant Scheme (FRGS, Sponsorship file number: FRGS/2/2014/SKK02/UITM/02/3) and Universiti Teknologi MARA through Bestari Perdana Grant (file number: 600-IRMI/DANA 5/3/BESTARI (P) 006/2018) and 241810/2016/RMJJ/15 for supporting this study. The authors wish to thank Professor Dr Azni Zain Ahmed of InQKA, Universiti Teknologi MARA, Malaysia for proofreading the article.

\section{References}

1. Knutson, U., Dahlgren, J., Marcus, C., Rosberg, S., Bronnegard, M., Stierna, P. and Albertsson-Wikland, K. (1997). Circadian cortisol rhythms in healthy boys and girls: Relationship with age, growth, body composition, and pubertal development. Journal of Clinical Endocrinology and Metabolism, 82(2): 536.

2. Aube, B. L. L., Curbow, B. A., Ostello, R. W. and Fitzgerald, S. T. (2002). A pilot study examining the relationship between stress and serum cortisol concentrations in women with asthma. Respiratory Medicine, 96: $823-828$.

3. Lee, S., Lim, H. S., Shin, H. J., Kim, S. A., Park, J., Kim, H.C., Kim, H., Kim, H. J., Kim, Y.T., Lee, K. R. and Kim, Y. J. (2014). Simultaneous determination of cortisol and cortisone from human serum by liquid chromatography-tandem mass spectrometry. Journal of Analytical Methods in Chemistry, 2014: 787483.

4. De Palo, E. F., Antonelli, G., Benetazzo, A., Prearo, M. and Gatti, R. (2009). Human saliva cortisone and cortisol simultaneous analysis using reverse phase HPLC technique. Clinica Chimica Acta, 405: 60 - 65.

5. Ray, J. A., Kushnir, M. M., Rockwood, A. L. and Meikle, A. W. (2011). Analysis of cortisol, cortisone and dexamethasone in human serum using liquid chromatography-tandem mass spectrometry and assessment of cortisol: Cortisone ratios in patients with impaired kidney function. Clinica Chimica Acta, 412: 1221 - 1228.

6. Lee, S., Kwon, S., Shin, H. J., Lim, H. S., Singh, R. J., Lee, K. R. and Kim. Y. J. (2010). Simultaneous quantitative analysis of salivary cortisol and cortisone in Korean adults using LC-MS/MS. BMB Reports, 43(7): $506-511$.

7. Zhai, X., Chen, F., Zhu, C. and Lu. Y. (2015). A simple LC-MS/MS method for the determination of cortisol, cortisone and tetrahydro-metabolites in human urine: Assay development, validation and application in depression patients. Journal of Pharmaceutical and Biomedical Analysis, 107: 450 - 455. 
Hazirah et al: METHOD DEVELOPMENT AND VALIDATION FOR QUANTIFICATION OF CORTISOL AND CORTISONE USING ULTRA-HIGH PERFORMANCE LIQUID CHROMATOGRAPHYTANDEM MASS SPECTROMETRY

8. Levine, A., Zagoory-Sharon, O., Feldman, R., Lewis, J. G., and Weller. A. (2007). Measuring cortisol in human psychobiological studies. Physiology and Behavior, 90(1): 43 - 53.

9. Milam, J., Slaughter, R., Verma, G. and McConnell. R. (2014). Hair cortisol, perceived stress and dispositional optimism: a pilot study among adolescents. Journal of Traumatic Stress Disorders \& Treatment, 3(3): 1 - 13.

10. Herane Vives, A., De Angel, V., Papadopoulos, A., Strawbridge, R., Wise, T., Young, A. H., Arnone, D. and Cleare. A. J. (2015). The relationship between cortisol, stress and psychiatric illness: New insights using hair analysis. Journal of Psychiatric Research, 70: $38-49$.

11. Pani, S. C., Al Askar, A. M., Al Mohrij, S. I. and Al Ohali, T. A. (2011). Evaluation of stress in final-year Saudi dental students using salivary cortisol as a biomarker. Journal of Dental Education, 75(3): 377 - 384.

12. Lundberg, U. (2005). Stress hormones in health and illness: The roles of work and gender. Psychoneuroendocrinology, 30(10): 1017 - 1021.

13. Institute for Public Health (2015). National Health and Morbidity Survey 2015 (NHMS 2015): NonCommunicable Diseases, Vol. II. San Diego, California.

14. Armitage, C. J., Panagioti, M., Rahim, W. A., Rowe, R., O'Connor, R. C. (2015). Completed suicides and selfharm in Malaysia: A systematic review. General Hospital Psychiatry, 37(2): $153-165$.

15. Singh, R., Goyal, M., Tiwari, S., Ghildiyal, A., Nattu, S. M. and Das, S. (2012). Effect of examination stress on mood, performance and cortisol levels in medical students. Indian Journal of Physiology and Pharmacology, 56(1): $48-55$.

16. Owen, L. J., Adaway, J. E., Davies, S., Neale, S., El-Farhan, N., Ducroq, D., Evans, C., Rees, D. A., Mackenzie, F. and Keevil, B. G. (2013). Development of a rapid assay for the analysis of serum cortisol and its implementation into a routine service laboratory. Annals of Clinical Biochemistry, 50(4): 345 -352.

17. Turpeinen, U. and Hämäläinen, E. (2013). Determination of cortisol in serum, saliva and urine. Best Practice and Research: Clinical Endocrinology and Metabolism, 27(6): 795 - 801.

18. Monaghan, P. J., Keevil, B. G. and Trainer, P. J. (2013). The use of mass spectrometry to improve the diagnosis and the management of the HPA axis. Reviews in Endocrine \& Metabolic Disorder, 14(2): 143 - 157.

19. Lopes Alves, A. N., Mendonca, B. B. and Valassi, H. P. L. (2015). Analytical performance of LC-MS/MS method for simultaneous determination of five steroids in serum. Mass Spectrometry \& Purification Techniques, 1(2): $1-5$.

20. Huang, W., Kalhorn, T. F., Baillie, M., Shen, D. D. and Thummel, K. E. (2007). Determination of free and total cortisol in plasma and urine by liquid chromatography-tandem mass spectrometry. Therapeutic Drug Monitoring, 29 (2): 215 - 224.

21. Kushnir, M. M., Rockwood, A. L., Roberts, W. L., Yue, B., Bergquist, J. and Meikle, A. W. (2011). Liquid chromatography-tandem mass spectrometry for analysis of steroids in clinical laboratories. Clinical Biochemistry, 44(1): 77 - 88 .

22. Cao, Z., West, C., Norton-Wenzel, C. and Rej, R. (2009). Effects of resin or charcoal treatment on fetal bovine serum and bovine calf serum. Endocrine Research, 34(4): 101 - 108.

23. Ifelebuegu, A. O. (2012). Removal of steroid hormones by activated carbon adsorption-kinetic and thermodynamic studies. Journal of Environmental Protection, 3(6): $469-475$.

24. Cooper, N., Khosravan, R., Erdmann, C., Fiene, J. and Lee, J. W. (2006). Quantification of uric acid, xanthine and hypoxanthine in human serum by HPLC for pharmacodynamic studies. Journal of Chromatography B: Analytical Technologies in the Biomedical and Life Sciences, 837: 1 - 10.

25. Ke, Y., Bertin, J., Gonthier, R., Simard, J. N. and Labrie, F. (2014). A sensitive, simple and robust LC-MS/MS method for the simultaneous quantification of seven androgen- and estrogen-related steroids in postmenopausal serum. Journal of Steroid Biochemistry and Molecular Biology, 144: 523 - 534.

26. Sánchez-Guijo, A., Oji, V., Hartmann, M. F., Traupe, H. and Wudy, S. A. (2015). Simultaneous quantification of cholesterol sulfate, androgen sulfates, and progestagen sulfates in human serum by LC-MS/MS. Journal of Lipid Research, 56(9): 1843 - 1851.

27. European Medicines Agency (2011). Guideline on bioanalytical method validation. Access from http://www.ema.europa.eu/docs/en_GB/document_library/Scientific_guideline/2011/08/WC500109686.pdf

28. Tai, S. S.-C. and Welch, M. J. (2004). Development and evaluation of a candidate reference method for the determination of total cortisol in human serum using isotope dilution liquid chromatography/mass spectrometry and liquid chromatography/tandem mass spectrometry. Analytical Chemistry, 76 (4): 1008 - 1014. 
29. DiFrancesco, R., Frerichs, V., Donnelly, J., Hagler, C., Hochreiter, J. and Tornatore, K. M. (2007). Simultaneous determination of cortisol, dexamethasone, methylprednisolone, prednisone, prednisolone, mycophenolic acid and mycophenolic acid glucuronide in human plasma utilizing liquid chromatographytandem mass spectrometry. Journal of Chromatography B: Analytical Technologies in the Biomedical and Life Sciences, 859(1): $42-51$.

30. Ionita, I. A., Fast, D. M. and Akhlaghi, F. (2009). Development of a sensitive and selective method for the quantitative analysis of cortisol, cortisone, prednisolone and prednisone in human plasma. Journal of Chromatography B: Analytical Technologies in the Biomedical and Life Sciences, 877: 765 - 772.

31. Brinc, D., Chan, M. K., Venner, A. A., Pasic, M. D., Colantonio, D., Kyriakopolou, L. and Adeli, K. (2012). Long-term stability of biochemical markers in pediatric serum specimens stored at $-80{ }^{\circ} \mathrm{C}$ : A CALIPER sub study. Clinical Biochemistry, 45: $816-826$. 